\title{
Pengembangan LKS Berbasis Contextual Teaching and Learning (CTL) Pada Pembelajaran IPA di SDN Sakuru
}

\author{
Arif Rahman Hakim ${ }^{1)}$, Hairunisa ${ }^{1{ }^{*}}$, Makasih ${ }^{1)}$, Abd. Haris ${ }^{1)}$ \\ ${ }^{1)}$ STKIP Taman Siswa Bima \\ *anis010286@gmail.com
}

Abstrak: Penelitian ini bertujuan untuk menghasilkan LKS berbasis CTL yang efektif dalam meningkatkan hasil belajar siswa pada pembelajaran IPA materi daur air kelas V SDN Sakuru. Jenis Penelitian ini adalah penelitian Research and Development (RED) yang terdiri dari beberapa tahap, meliputi: potensi dan masalah, pengumpulan data, desain produk, validasi desain, revisi desain, ujicoba produk, ujicoba pemakaian dan produksi masal. Subjek penelitian ini adalah siswa kelas V SDN Sakuru. Uji coba produk dilakukan di kelas VI dengan jumlah 10 siswa dan uji coba pemakaian dilakukan di kelas $\mathrm{V}$ dengan jumlah 26 siswa. Teknik analisis data menggunakan uji deskriptif, (1) Analisis kelayakan produk dari Tim Ahli, (2) Analisis peningkatan hasil belajar siswa yaitu dengan mencari nilai rata-rata dan ketuntasan klasikal yang diperoleh dari pretest dan posttest siswa. Hasil penelitian menunjukkan bahwa: (1) LKS yang dikembangkan mengandung komponen CTL yang terdiri dari kegiatan percobaan dan pengamatan; (2) LKS berbasis CTL valid berdasarkan validasi dari Tim ahli dan Guru; (3) LKS berbasis CTL dapat meningkatkan hasil belajar siswa yang ditunjukkan dengan nilai rata-rata pretest 65,16 dan rata-rata nilai posttest 81,15 , sedangkan ketuntasan secara klasikal pada pretest $42,3 \%$ sedangkan pada posttest meningkat menjadi $88,45 \%$. Simpulan penelitian ini adalah LKS yang dikembangkan dapat meningkatkan hasil belajar siswa.

Kata Kunci: Pengembangan LKS, CTL, Pembelajaran IPA

\section{Pendahuluan}

Pada dasarnya tujuan dari pembelajaran IPA itu sendiri yaitu menciptakan manusia yang berpengetahuan dan mengerti akan lingkungannya, tidak hanya paham secara teoritis tetapi paham akan temuannya sendiri di lingkungan mereka (Hairunisa et al., 2019). Adapun ruang lingkup bahan kajian IPA untuk SD/MI meliputi beberapa aspek berikut ini: (1) mahluk hidup dan proes kehidupan, meliputi manusia, hewan, tumbuhan, dan interaksinya dengan lingkungan serta kesehatan; (2) benda/materi,sifat-sifat dan kegunaanya meliputi: cair, padat, dan gas; (3) energi dan perubahanya meliputi: gaya, bunyi, panas, magnet, listrik, cahaya dan pesawat sederhana; (4) bumi dan alam semesta: tanah, bumi, tata surya, dan benda-benda langit lainnya (Apriani et al., 2017).

Tujuan dan ruang lingkup dari mata pelajaran IPA yang tercantum dalam Kurikulum 2013 tersebut sudah jelas bahwa IPA merupakan mata pelajaran yang erat kaitannya dengan lingkungan dan kehidupan sehari-hari (Susiloningsih, 2015). Namun kenyataanya implementasi pembelajaran IPA belum relevan dengan tujuan yang diharapkan, dan keterkaitan mata pelajaran IPA dengan lingkungan juga masih kurang. Permasalahan yang terjadi tersebut merupakan hasil nyata dari pembelajaran IPA yang masih belum berjalan dengan baik dan juga belum sesuai dengan apa yang diharapkan (P \& Hidayat, 2019).

Berdasarkan hasil pengamatan di lapangan, ditemukan masalah mengenai hasil belajar IPA yang masih rendah. Hal tersebut terbukti dengan ditemukannya beberapa masalah, diantaranya adalah kegiatan pembelajaran mata pelajaran IPA kurang mengadakan kegiatan pengamatan dan percobaan-percobaan secara langsung terhadap materi yang diajarkan sehingga siswa terkesan hanya mendengarkan penjelasan guru dan menghafal buku teks. Lembar Kegiatan Siswa (LKS) terpaku pada teks materi dan soal-soal, dan kurang mengembangkan kegiatan siswa yang berkaitan langsung dengan lingkungan siswa. Guru juga belum mempunyai 
susunan Lembar Kegiatan Siswa (LKS) yang sesuai dengan karakteristik mata pelajaran IPA dan karakteristik lingkungan belajar siswa, sehingga LKS yang digunakan bisa lebih kontekstual. Guru kurang mengaitkan materi pembelajaran dengan kehidupan nyata, sehingga pengalaman belajar siswa belum terkonsep dalam kehidupan sehari-hari atau kehidupan nyata.

Permasalahan didukung dari hasil belajar siswa kelas V mata pelajaran IPA pada saat Ujian Akhir Semester (UAS) semester 1 . Hanya ada 12 siswa $(46,15 \%)$ dari 26 siswa yang nilainya diatas Kriteria Ketuntasan Minimal (KKM) yaitu 70. Data tersebut menunjukkan bahwa dalam pembelajaran IPA sangatlah perlu adanya rekonstruksi kegiatan pembelajaran dan perlu adanya pembelajaran yang inovatif untuk meningkatkan kualitas pembelajaran IPA. Permasalahan dalam pembelajaran IPA tersebut sangatlah penting dan harus disegerakan untuk dicari alternatif pemecahan masalahnya, guna memperbaiki kualitas pembelajaran IPA di SDN Sakuru.

Bahan ajar sangatlah penting dalam proses pembelajaran, guna mewujudkan pembelajaran IPA sesuai dengan hakikatnya (Hairunisa \& Arif Rahman Hakim, 2018). Melihat hal tersebut peneliti melakukan alternatif tindakan dengan mengembangkan bahan ajar siswa. Bahan ajar siswa yang peneliti kembangkan yaitu berupa LKS dengan berbasis CTL, yang peneliti kembangkan lebih inovatif dan sesuai dengan karakteristik IPA (Lestari et al., 2018). Siswa diajak mengaitkan materi dengan kegiatan sehari-hari mereka dan juga langsung diajak untuk kerja ilmiah, sehingga pembelajaran lebih bermakna untuk siswa. Pendekatan kontekstual ini dapat membantu siswa belajar secara berkembang, menemukan pengetahuannya sendiri berdasarkan tingkat perkembangan dan pengalaman yang dimilikinya melalui lingkungan sebagai sumber belajar, dan dapat mengembangkan keterampilan siswa, sehingga siswa lebih aktif dan kreatif (Hasanah et al., 2006).

Diharapkan dengan mengembangkan LKS berbasis CTL siswa dapat belajar lebih aktif dan kreatif, materi pelajaran yang diajarkan dipahami secara mendalam bukan hanya hafalan belaka, serta dapat menghubungkan materi yang didapat dengan kehidupannya sehari-hari (Trisnawati \& Prasetyo, 2020). Selain itu, pengembangan LKS ini diharapkan sesuai dengan karakteristik pembelajaran IPA di Sekolah Dasar, serta efektif dan praktis digunakan untuk meningkatkan kualitas pembelajaran yang bisa mendorong keterlibatan siswa secara aktif dalam pembelajaran dan mempermudah siswa dalam mengingat materi yang diajarkan dalam proses pembelajaran serta hasil belajar mata pelajaran IPA kelas V SDN Sakuru dapat meningkat.

\section{Metode}

Metode penelitian yang digunakan dalam penelitian ini yaitu jenis metode penelitian pengembangan (Research and Development) (Refianti et al., 2019). Penelitian pengembangan yang dilakukan ini yaitu mengembangkan LKS dalam pembelajaran IPA materi daur air. Penelitian ini bertujuan untuk menguji keefektifan produk pengembangan LKS berbasis CTL pada pembelajaran IPA materi daur air kelas V SDN Sakuru. Langkah-langkah dalam penelitian ini seperti pada Gambar 1, yaitu: (1) potensi dan masalah; (2) pengumpulan data; (3) desain produk; (4) validasi desain; (5) revisi desain; (6) uji coba produk; (7) revisi produk; (8) uji coba pemakaian; (9) revisi produk; (10) produksi masal (Nurwati, 2018).

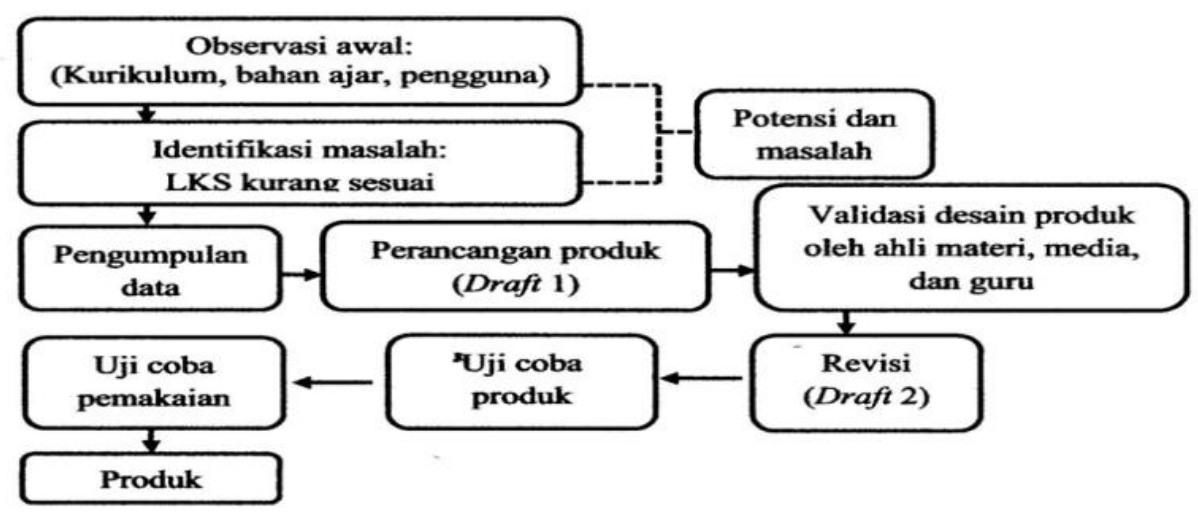

Gambar 1. Prosedur Penelitian

Penelitian ini dilaksanakan di SDN Sakuru pada semester II tahun ajaran 2018/2019. Sampel penelitian ini adalah siswa kelas V SDN Sakuru tahun ajaran 2018/2019 yang berjumlah 26 siswa. Dalam penelitian ini ada dua variabel yang digunakan, 1) Variabel bebas dalam penelitian ini yaitu pembelajaran menggunakan LKS 
berbasis CTL pada pembelajaran IPA materi daur air kelas V SDN Sakuru. 2) Variabel terikat dalam penelitian ini yaitu hasil belajar siswa mata pelajaran IPA.

Adapun analisis data dibagi dalam dua bagian yaitu analisis data produk dan analisis peningkatan hasil belajar siswa dari penggunaan LKS. Analisis data produk dibagi lagi menjadi dua yaitu analisis kelayakan produk dan analisis tanggapan guru dan siswa. Analisis kelayakan produk diambil dari penilaian instrumen kelayakan produk LKS berbasis CTL oleh Tim ahli sedangkan analisis tanggapan guru dan siswa diambil dari angket yang diberikan siswa dan guru pada saat uji coba produk dan uji coba pemakaian. Peningkatan hasil belajar diukur dari hasil tes pretest yang diberikan sebelum menggunakan LKS Berbasis CTL dan tes posttest yang diberikan setelah pembelajaran menggunakan LKS Berbasis CTL yaitu dengan menghitung Rata-rata kelas dan ketuntasan secara klasikal.

\section{Hasil dan Pembahasan}

Penelitian pengembangan yang dilakukan ini menghasilkan suatu produk LKS berbasis CTL pada pembelajaran IPA materi daur air kelas V SD. Penelitian ini dilakukan dengan mengadaptasi model pengembangan dari Sugiyono. Prosedur penelitian ini terdiri dari beberapa tahapan yaitu: (1) potensi dan masalah; (2) pengumpulan data; (3) desain produk; (4) validasi desain; (5) revisi desain; (6) uji coba produk; (7) uji coba pemakaian; (8) produksi masal (MULYANI, 2019). Penjelasan hasil penelitian dari beberapa tahapan tersebut dijelaskan berikut ini.

\section{Potensi dan Masalah}

Pada tahap ini potensi dan masalah didapatkan dari beberapa tahapan. Potensi dan masalah yang ada ditemukan dengan menganalisis kebutuhan diawal proses penelitian. Proses analisis kebutuhan tersebut terdiri dari proses analisis kurikulum, analisis bahan ajar, dan analisis pengguna.

\section{Pengumpulan Data}

Pada tahap pengumpulan data berkaitan dengan pembuatan produk LKS berbasis CTL peneliti menyiapkan beberapa data antara lain: (1) data awal hasil observasi; (2) perangkat pembelajaran seperti RPP, media dan alat peraga; (3) materi pelajaran yang digunakan untuk pembuatan produk LKS berbasis CTL; (4) menyiapkan sumber belajar berupa lingkungan.

\section{Desain Produk}

Desain LKS Berbasis CTL pada pembelajaran IPA materi daur air merupakan pengembangan LKS yang berintegrasikan pendekatan CTL. Komponen-komponen CTL diintegrasikan kedalam LKS yang meliputi tujuh komponen, yaitu: (1) konstruktivisme; (2) menemukan; (3) bertanya; (4) masyarakat belajar; (5) pemodelan; (6) refleksi; (7) penilaian yang sebenarnya (Lamapaha, 2017). Sehingga produk LKS yang dihasilkan lebih bermakna bagi anak dalam hal memahami dan mengingat materi.

\section{Validasi Desain Produk}

Penilaian mengenai kevalidan produk LKS berbasis CTL dilakukan oleh Tim ahli. Uji kevalidan digunakan untuk menguji layak atau tidaknya LKS IPA berbasis CTL digunakan dalam pembelajaran. Uji kelayakan produk dilakukan pada tahap validasi desain. Uji kelayakan pada tahap validasi desain terdiri dari empat aspek yaitu: (1) aspek kelayakan isi; (2) aspek kelayakan penyajian; (3) aspek kebahasaan; dan (4) aspek penilaian CTL (Maemunah \& Pramesti, 2019). Uji kelayakan LKS untuk ahli media terdiri dari aspek kelayakan kegrafikan. Tahap uji kelayakan berikutnya yaitu berdasarkan penilaian yang dilakukan oleh guru mata pelajaran kelas $\mathrm{V}$ tempat penelitian, guru sebagai praktisi pendidikan. Uji kelayakan yang dilakukan oleh guru terdiri dari 4 aspek yaitu: (1) aspek kelayakan isi; (2) aspek kelayakan penyajian; dan (3) aspek kebahasaan; dan (4) penilaian CTL. Masing-masing perolehan skor validasi penilaian dari masing-masing validator terdapat 4 kriteria penilaian, meliputi sangat layak dengan rentang $82 \%-100 \%$, layak dengan rentang $63 \%-81 \%$, cukup layak dengan rentang skor 44\% - 62\%, dan tidak layak dengan rentang 25\% - 43\% (Bahri \& Widodo, 2017).

Pada tahap validasi desain penilaian dilakukan oleh Tim ahli. Setiap aspek dalam penilaian ditanyakan dalam 4 kriteria, yaitu meliputi kriteria sangat baik, baik, cukup, dan kurang. Hasil rata-rata penilaian validasi desain dapat dilihat pada tabel berikut. 
Tabel 1. Persentase Penilaian Produk LKS oleh Ahli

\begin{tabular}{cccccccc}
\hline \multirow{2}{*}{ No } & \multirow{2}{*}{ Validator } & \multicolumn{7}{c}{ Aspek Penilaian } & \multirow{2}{*}{ Presentase (Kriteria) } \\
\cline { 3 - 7 } & Isi & Penyajian & Ctl & Kegrafikan & Kebahasaan & \\
\hline 1 & I & 18 & 13 & 27 & - & - & $85 \%$ (Sangat layak) \\
2 & II & - & - & - & - & 16 & $80 \%$ (layak) \\
3 & III & - & - & - & 22 & - & $92 \%$ (Sangat layak) \\
4 & IV & - & - & - & 20 & - & $83 \%$ (sangat layak) \\
5 & V & 15 & 12 & 22 & - & 15 & $73 \%$ (layak) \\
\hline
\end{tabular}

Berdasarkan table 1 diatas menunjukkan bahwa masing masing validator memberi nilai $>63 \%$, yang berarti produk LKS berbasis CTL yang dikembangkan memenuhi kriteria layak.

Tabel 2. Persentase Penilaian Produk LKS Setiap Aspek

\begin{tabular}{cccccc}
\hline No & Aspek Penilaian & Rata-rata Skor & Jumlah Skor & Persentase (\%) & Kriteria \\
\hline 1 & Isi & 16,5 & 20 & 82 & Sangat Layak \\
2 & Penyajian LKS & 12,5 & 16 & 78 & Layak \\
3 & Penilaian CTL & 24,5 & 32 & 77 & Layak \\
4 & Kegrafikan & 21 & 24 & 87 & Layak \\
5 & Kebahasaan & 15,5 & 20 & 77 & Layak \\
\hline
\end{tabular}

Tabel 2 diatas menunjukkan bahwa masing masing validator memberi nilai $>63 \%$ terhadap aspek-aspek yang diujikan, yang berarti produk LKS berbasis CTL yang dikembangkan memenuhi kriteria layak. Aspek kelayakan isi skor persentase sebesar 82\% (sangat layak), aspek kelayakan penyajian skor persentase sebesar 78\% (layak), aspek penilaian CTL skor persentase sebesar 77\% (layak), aspek penilaian kelayakan kegrafikan skor persentase sebesar 87\% (layak), aspek penilaian kebahasaan skor persentase sebesar 77\% (layak).

Simpulan lembar validasi dari validator menunjukkan bahwa LKS berbasis CTL pada pembelajaran IPA yang dikembangkan layak digunakan sebagai panduan belajar dalam pembelajaran dengan revisi, sehingga harus dilakukan revisi sesuai saran dan komentar dari masing-masing validator terlebih dahulu sebelum melangkan ke tahap berikutnya. Kelayakan dari masing masing validator dapat dilihat dari persentase penilaian yang menunjukkan $>63 \%$.

\section{Uji Coba Produk}

Uji coba produk dilakukan skala kecil dengan memberikan pembelajaran terhadap 10 siswa dari kelas VI SDN Sakuru. Pembelajaran menggunakan LKS berbasis CTL pada pembelajaran IPA materi daur air. Uji coba produk skala kecil dilakukan bertujuan untuk menguji keterterapan LKS berbasis CTL dengan melihat respon dan komentar sebelum di uji cobakan pada skala yang lebih besar. Setelah siswa belajar menggunakan LKS berbasis CTL, kemudian siswa diminta untuk mengisi angket tanggapan. Hasil tanggapan siswa digunakan untuk pertimbangan perbaikan terhadap produk LKS yang dikembangkan. Hasil rekapitulasi angket tanggapan siswa uji coba produk disajikan pada tabel 3 .

Berdasarkan data angket tanggapan siswa uji coba produk pada tabel 3 dari ke 10 siswa kelas VI SDN Sakuru menunjukkan tanggapan yang positif bagi produk LKS berbasis CTL yang diuji cobakan. Hal tersebut ditunjukkan dengan hasil persentase paling rendah hanya $85 \%$ untuk aspek 2 yaitu LKS IPA berbeda dari bahan ajar biasanya. Sedangkan persentase paling tinggi 92\% untuk aspek 4 dan 5 yaitu Gambar di dalam LKS IPA memudahkan dalam memahami materi dan kegiatan belajar dalam LKS IPA menyenangkan. Persentase klasikal mendapatkan 88,5\% dengan kriteria sangat positif.

\section{Uji Coba Pemakaian Produk}

Uji coba pemakaian dilakukan skala besar dengan memberikan pembelajaran terhadap 26 siswa dari kelas V SDN Sakuru. LKS berbasis CTL pada pembelajaran IPA materi daur air digunakan sebagai penunjang proses pembelajaran. Uji coba pemakaian dilakukan di kelas yang belum menggunakan LKS berbasis CTL. Guru sebelumnya mempersiapkan lembar soal pretest dan posttest. Sebelum pembelajaran siswa diberi soal pretest dan sesudah pembelajaran siswa diberi soal posttest. 
Tabel 3. Rekapitulasi Hasil Angket Tanggapan Siswa Uji Coba Produk

\begin{tabular}{|c|c|c|c|c|c|}
\hline No & Aspek yang ditanyakan & Nilai Maksimal & Nilai siswa & Persentase & Kriteria \\
\hline 1 & $\begin{array}{l}\text { Ketertarikan untuk mempelajari LKS } \\
\text { IPA }\end{array}$ & 40 & 36 & $90 \%$ & Sangat Positif \\
\hline 2 & $\begin{array}{l}\text { LKS IPA berbeda dari bahan ajar } \\
\text { biasanya }\end{array}$ & 40 & 34 & $85 \%$ & Sangat Positif \\
\hline 3 & $\begin{array}{l}\text { Materi yang disampaikan LKS IPA } \\
\text { mudah dipahami }\end{array}$ & 40 & 35 & $87 \%$ & Sangat Positif \\
\hline 4 & $\begin{array}{l}\text { Gambar di dalam LKS IPA } \\
\text { memudahkan dan memahami materi }\end{array}$ & 40 & 37 & $92 \%$ & Sangat Positif \\
\hline 5 & $\begin{array}{l}\text { Kegiatan belajar dalam LKS IPA } \\
\text { menyenangkan }\end{array}$ & 40 & 37 & $92 \%$ & Sangat Positif \\
\hline 6 & $\begin{array}{l}\text { LKS IPA dapat menumbuhkan } \\
\text { kemandirian dalam belajar }\end{array}$ & 40 & 35 & $87 \%$ & Sangat Positif \\
\hline 7 & $\begin{array}{l}\text { LKS IPA mempermudah dalam } \\
\text { memahami materi daur air }\end{array}$ & 40 & 35 & $87 \%$ & Sangat Positif \\
\hline 8 & Penyajian LKS IPA sangat menarik & 40 & 36 & $90 \%$ & Sangat Positif \\
\hline 9 & Penggunaan simbol sesuai aturan & 40 & 34 & $87 \%$ & Sangat Positif \\
\hline \multirow[t]{4}{*}{10} & $\begin{array}{l}\text { LKS IPA menumbuhkan rasa ingin tahu } \\
\text { untuk mempelajari lebih lanjut }\end{array}$ & 40 & 35 & $87 \%$ & Sangat Positif \\
\hline & Jumlah & 400 & 354 & & \\
\hline & Persentase secara klasikal & $88.5 \%$ & & & \\
\hline & Kriteria & Sangat Positif & & & \\
\hline
\end{tabular}

Guru melakukan pembelajaran menggunakan LKS berbasis CTL sesuai dengan penggalan silabus dan RPP yang telah dipersiapkan. Setelah pembelajaran dan posttest selesai, kemudian guru dan siswa diminta untuk memberikan respons melalui angket tanggapan terhadap produk LKS yang dikembangkan. Hasil respons guru dan respons siswa digunakan untuk pertimbangan perbaikan dan sebagai acuan kepraktisan produk LKS yang dikembangkan. Rekapitulasi respons siswa disajikan pada tabel berikut ini.

Tabel 4. Rekapitulasi Hasil Respons Siswa Uji Coba Pemakaian

\begin{tabular}{|c|c|c|c|c|c|}
\hline No & Aspek yang ditanyakan & Nilai Maksimal & Nilai siswa & Persentase & Kriteria \\
\hline 1 & $\begin{array}{l}\text { Ketertarikan untuk mempelajari LKS } \\
\text { IPA }\end{array}$ & 104 & 92 & $88 \%$ & Sangat Positif \\
\hline 2 & $\begin{array}{l}\text { LKS IPA berbeda dari bahan ajar } \\
\text { biasanya }\end{array}$ & 104 & 84 & $81 \%$ & Positif \\
\hline 3 & $\begin{array}{l}\text { Materi yang disampaikan LKS IPA } \\
\text { mudah dipahami }\end{array}$ & 104 & 86 & $82 \%$ & Sangat Positif \\
\hline 4 & $\begin{array}{l}\text { Gambar di dalam LKS IPA } \\
\text { memudahkan dan memahami materi }\end{array}$ & 104 & 89 & $85 \%$ & Sangat Positif \\
\hline 5 & $\begin{array}{l}\text { Kegiatan belajar dalam LKS IPA } \\
\text { menyenangkan }\end{array}$ & 104 & 82 & $79 \%$ & Positif \\
\hline 6 & $\begin{array}{l}\text { LKS IPA dapat menumbuhkan } \\
\text { kemandirian dalam belajar }\end{array}$ & 104 & 82 & $79 \%$ & Positif \\
\hline 7 & $\begin{array}{l}\text { LKS IPA mempermudah dalam } \\
\text { memahami materi daur air }\end{array}$ & 104 & 84 & $81 \%$ & Positif \\
\hline 8 & Penyajian LKS IPA sangat menarik & 104 & 83 & $80 \%$ & Positif \\
\hline 9 & Penggunaan simbol sesuai aturan & & 82 & $79 \%$ & Positif \\
\hline \multirow[t]{4}{*}{10} & $\begin{array}{l}\text { LKS IPA menumbuhkan rasa ingin } \\
\text { tahu untuk mempelajari lebih lanjut }\end{array}$ & 104 & 90 & $86 \%$ & Sangat Positif \\
\hline & Jumlah & 1040 & 854 & & \\
\hline & Persentase secara klasikal & $82 \%$ & & & \\
\hline & Kriteria & Sangat Positif & & & \\
\hline
\end{tabular}


Berdasarkan data pada tabel 4, hasil respons siswa uji coba pemakaian dari ke 26 siswa kelas V SDN Sakuru menunjukkan tanggapan yang positif bagi produk LKS berbasis CTL yang diuji cobakan. Hal tersebut ditunjukkan dengan hasil persentase paling rendah hanya 79\% untuk aspek 5, 6, dan 9. Sedangkan persentase paling tinggi yaitu $88 \%$ untuk aspek 1 yaitu ketertarikan untuk mempelajari LKS IPA. Sedangkan respons siswa secara klasikal diperoleh skor $82 \%$ dengan kriteria sangat positif. Untuk rekapitulasi hasil respons guru disajikan pada tabel berikut ini.

Tabel 5. Rekapitulasi Hasil Respon Guru Uji Coba Pemakaian

\begin{tabular}{|c|c|c|c|c|c|}
\hline No & Aspek yang ditanyakan & Nilai Maksimal & $\begin{array}{l}\text { Nilai yang } \\
\text { diperoleh }\end{array}$ & Persentase & Kriteria \\
\hline 1 & $\begin{array}{l}\text { Penampilan LKS IPA secara } \\
\text { keseluruhan menarik }\end{array}$ & 4 & 3 & $75 \%$ & Positif \\
\hline 2 & $\begin{array}{l}\text { Bahasa yang digunakan dalam } \\
\text { LKS IPA mudah dipahami }\end{array}$ & 4 & 3 & $75 \%$ & Positif \\
\hline 3 & $\begin{array}{l}\text { Penyajian LKS IPA tersusun } \\
\text { secara sistematis }\end{array}$ & 4 & 2 & $50 \%$ & Cukup Positif \\
\hline 4 & $\begin{array}{l}\text { LKS IPA sesuai dengan tujuan } \\
\text { pembelajaran }\end{array}$ & 4 & 3 & $75 \%$ & Positif \\
\hline 5 & $\begin{array}{l}\text { Penggunaan gambar dalam LKS } \\
\text { IPA jelas }\end{array}$ & 4 & 4 & $100 \%$ & Sangat Positif \\
\hline 6 & $\begin{array}{l}\text { Kegiatan praktikum merangsang } \\
\text { kemampuan berpikir kritis }\end{array}$ & 4 & 2 & $50 \%$ & Cukup Positif \\
\hline 7 & $\begin{array}{l}\text { Jenis kegiatan dalam LKS IPA } \\
\text { bervariasi }\end{array}$ & 4 & 2 & $50 \%$ & Cukup Positif \\
\hline 8 & $\begin{array}{l}\text { LKS IPA membantu siswa materi } \\
\text { daur air }\end{array}$ & 4 & 4 & $100 \%$ & Sangat Positif \\
\hline 9 & $\begin{array}{l}\text { LKS IPA berbasis CTL berbeda } \\
\text { dari bahan ajar yang lain }\end{array}$ & 4 & 2 & $50 \%$ & Cukup Positif \\
\hline 10 & $\begin{array}{l}\text { LKS IPA dapat dipelajari secara } \\
\text { mandiri oleh siswa }\end{array}$ & 4 & 3 & $75 \%$ & Positif \\
\hline 11 & $\begin{array}{l}\text { LKS IPA mempermudah guru } \\
\text { mengevaluasi hasil belajar siswa }\end{array}$ & 4 & 3 & $75 \%$ & Positif \\
\hline & Jumlah & 44 & 31 & & \\
\hline & Persentase secara klasikal & $70.45 \%$ & & & \\
\hline & Kriteria & Positif & & & \\
\hline
\end{tabular}

Berdasarkan data pada tabel 5, hasil respon guru kelas V SDN Sakuru menunjukkan tanggapan yang positif untuk produk LKS berbasis CTL yang diuji cobakan. Hal tersebut ditunjukkan dengan hasil persentase paling rendah hanya 50\% untuk aspek 3, 6, 7, dan 9 . Sedangkan persentase paling tinggi yaitu $100 \%$ untuk aspek 8 . Sedangkan respons guru secara klasikal diperoleh skor 70,45\% dengan kriteria positif.

Berikut data perbandingan hasil belajar siswa yang diperoleh dari pretest (sebelum pembelajaran menggunakan LKS Berbasis CTL) dan posttest (setelah menggunakan LKS Berbasis CTL). Perolehan hasil belajar siswa saat pretest dan posttest disajikan dalam tabel berikut ini.

Tabel 6. Rekapitulasi hasil pretest dan posttest siswa

\begin{tabular}{ccccccc}
\hline Tindakan & $\begin{array}{c}\text { Nilai } \\
\text { Tertinggi }\end{array}$ & $\begin{array}{c}\text { Nilai } \\
\text { Terendah }\end{array}$ & Rata-rata & $\begin{array}{c}\text { Jumlah siswa } \\
\text { yang tuntas }\end{array}$ & $\begin{array}{c}\text { Jumlah siswa } \\
\text { tidak tuntas }\end{array}$ & $\begin{array}{c}\text { Ketuntasan } \\
\text { belajar (\%) }\end{array}$ \\
\hline Pretest & 80 & 50 & 65,16 & 11 & 15 & 42,3 \\
Posttest & 96 & 60 & 81,15 & 23 & 3 & 88,45 \\
\hline
\end{tabular}

Berdasarkan tabel di atas, nilai hasil belajar siswa pada saat pretest dan posttest mengalami perbedaan. Ratarata nilai pretest mendapatkan nilai 65,16 dan rata-rata nilai posttest mendapatkan nilai 81,15 . Selain itu ketuntasan belajar pada pretest dan posttest juga mengalami perbedaan, jumlah siswa tuntas pada pretest yaitu sejumlah 11 siswa (42,3\%) sedangkan pada saat posttest jumlah siswa tuntas berjumlah 23 siswa (88,45\%). Sehingga dapat 
disimpulkan bahwa terjadi peningkatan hasil belajar sebelum (pretest) dan sesudah (posttest) menggunakan produk LKS berbasis CTL. Perhitungan nilai tersebut sesuai dengan KKM (Kriteria Ketuntasan Minimal) yang dipatok pada mapel IPA untuk kelas V pada SD yang diteliti, bahwa siswa dianggap tuntas belajar jika mampu menyelesaikan soal mencapai 270 . Sehingga dapat disimpulkan bahwa terjadi peningkatan hasil belajar sebelum dan sesudah menggunakan produk LKS berbasis CTL baik secara individual maupun klasikal. Adanya peningkatan hasil belajar siswa tersebut menandakan bahwa penggunaan LKS berbasis CTL berpengaruh terhadap hasil belajar siswa, sehingga dapat dijadikan alternatif pilihan dalam pembelajaran IPA khusunya materi daur air. Hal ini sesuai dengan hasil penelitian yang telah dilakukan oleh (Budiono, 2014).

\section{Simpulan}

Berdasarkan hasil analisis data dan pembahasan pada penelitian dapat diambil simpulan sebagai berikut: (1) Produk LKS yang dikembangkan berkarakteristik CTL, yang terdiri atas kegiatan-kegiatan percobaan, penyelidikan dan pengamatan, dan pengembangan LKS juga disesuaikan dengan perkembangan kognitif anak usia SD. (2) Produk LKS berbasis CTL pada pembelajaran IPA materi daur air telah memenuhi kriteria valid dari penilaian para ahli pada aspek kelayakan isi, kelayakan penyajian, kegrafikan, kebahasaan, dan CTL. (3) Produk LKS berbasis CTL pada pembelajaran IPA materi daur air dapat meningkatkan hasil belajar siswa, terbukti dengan Rata-rata nilai pretest mendapatkan nilai 65,16 dan rata-rata nilai posttest mendapatkan nilai 81,15 dan selisish ratarata 15,99 . Selain itu ketuntasan belajar pada pretest dan posttest juga mengalami perbedaan, jumlah siswa tuntas pada pretest yaitu sejumlah 11 siswa (42,3\%) sedangkan pada saat posttest jumlah siswa tuntas berjumlah 23 siswa $(88,45 \%)$.

\section{Ucapan Terima Kasih}

Peneliti mengucapkan terimakasih kepada ketua STKIP Taman Siswa Bima dan Kepala Sekolah SDN Sakuru yang telah memberikan kesempatan dan izin pada Tim kami untuk melakukan penelitian ini sehingga penelitian ini dapat terlaksana.

\section{Daftar Pustaka}

Apriani, A., Buyung, B., \& Relawati, R. (2017). Pengembangan Lembar Kerja Siswa (LKS) Berbasis Contextual Teaching And Learning (CTL) pada Materi Faktorisasi Suku Aljabar Kelas VIII SMP Negeri 9 Muaro .... PHI: Jurnal Pendidikan ..., 1(1). http://phi.unbari.ac.id/index.php/phi/article/view/7

Bahri, M. W. S., \& Widodo, W. (2017). Pengembangan Lembar Kerja Siswa (LKS) Fisika Berbasis Contextual Teaching and Learning (CTL) Untuk Meningkatkan Prestasi Belajar Siswa. Prosiding SNFA (Seminar Nasional Fisika Dan Aplikasinya), 2, 312. https://doi.org/10.20961/prosidingsnfa.v2i0.16420

Budiono, J. D. (2014). BioEdu BioEdu. 3(3), 571-579.

Hairunisa, \& Arif Rahman Hakim. (2018). Pengembangan Perangkat Pembelajaran IPA Model Inkuiri Terbimbing Berbasis Multiple Intelligences untuk Melatihkan Keterampilan Proses Sains Peserta Didik SMP. Jurnal Pendidikan Mipa, 8(1), 52-59. https://doi.org/10.37630/jpm.v8i1.58

Hairunisa, Arif Rahman Hakim, \& Nurjumiati. (2019). Studi Pengaruh Model Pembelajaran Berbasis Proyek (Project Based Learning) Terhadap Kreativitas Mahasiswa Program Studi PGSD Pada Mata Kuliah Konsep Dasar IPA. Jurnal Pendidikan Mipa, 9(2), 93-96. https://doi.org/10.37630/jpm.v9i2.190

Hasanah, U., Kimia, P. P., Program, D., \& Pendidikan, S. (2006). PENGEMBANGAN BAHAN AJAR CONTEXTUAL TEACHING AND LEARNING ( CTL ) BERBANTUAN MEDIA KOMPUTASI HYPERCHEM Dosen Program Studi Pendidikan Kimia , FPMIPA IKIP Mataram. 3(2), 309-312.

Lamapaha, Y. F. (2017). Pengembangan lembar kerja siswa berbasis kontekstual berorientasi penalaran saintifik. Jurnal Pendidikan Matematika Dan Sains, 5(1), 58-68. https://doi.org/10.21831/jpms.v5i1.13541

Lestari, A., Amelia, E., \& Marianingsih, P. (2018). Pengembangan Lembar Kerja Siswa Berbasis Ctl (Contextual Teaching and Learning) Sebagai Bahan Ajar Siswa Sma/Ma Kelas Xii Subkonsep Kultur in Vitro. Biosfer: Jurnal Pendidikan Biologi, 10(1), 32-44. https://doi.org/10.21009/biosferjpb.10-1.5 
Maemunah, S., \& Pramesti, D. I. (2019). Pengembangan Modul Jaringan Tumbuhan Berbasis Pendekatan Contextual Teaching and Learning (Ctl). Didaktika Biologi: Jurnal ..., 4, 67-81. http://jurnal.umpalembang.ac.id/dikbio/article/view/1923

MUlYANI, S. R. I. (2019). Pengembangan Lembar Kerja Siswa (LKS) Berbasis Kearifan Lokal Dengan Pendekatan Contextual Teaching And Learning (CTL) Untuk Meningkatkan .... 2(2). http://erepository.perpus.iainsalatiga.ac.id/id/eprint/6463

Nurwati, dkk. (2018). Pengembangan LKS Berbasis CTL pada Materi Aritmetika Sosial Untuk Meningkatkan Kemampuan Matematis Siswa The Student Development Sheet Based On Contextual Teaching and Learning In Main Disscussion Social Arithmetic to Increas Student Mathematical Ability. 20, 159-164.

P, B. I., \& Hidayat, P. (2019). Pengembangan Lembar Kerja Siswa (Lks) Berbasis Contextual Teaching and Learning Di Lingkungan Sekolah Pada Mata Pelajaran Ipa Kelas Iii Sd Muhamamdiyah Pakel Program Plus Yogyakarta. Jurnal Fundadikdas (Fundamental Pendidikan Dasar), $1(2), \quad 121$. https://doi.org/10.12928/fundadikdas.v1i2.654

Refianti, R., Marisa Z, M. Z., \& Mandasari, N. (2019). Pengembangan Lembar Kerja Siswa (LKS) Menggunakan Contextual Teaching and Learning (CTL) Berbasis Kota Lubuklinggau. Jurnal Pendidikan Matematika (JUDIKA EDUCATION), 2(2), 102-109. https://doi.org/10.31539/judika.v2i2.863

Susiloningsih, E. (2015). Lembar Kerja Siswa Berbasis Kontekstual dalam Pembelajaran Subtema "Aku Bangga dengan Daerah Tempat Tinggalku." Jurnal Inovasi Sekolah Dasar, 2, 100-106.

Trisnawati, P., \& Prasetyo, D. E. (2020). PENGEMBANGAN LEMBAR KERJA SISWA ( LKS ) BERBASIS MODEL CONTEXTUAL TEACHING AND LEARNING PADA MATERI PESAWAT SEDERHANA DI KELAS V SD NEGERI 04 KOTO SALAK. XIV(01), 99-112. 